\title{
Acne Necrotica (Varioliformis) - Case Report
}

\author{
Marija NIKOLIĆ ${ }^{1}$, Jelena PERIĆ1, 2 , Dušan ŠKILJEVIĆ1,2 \\ ${ }^{1}$ Clinic of Dermatovenereology, Clinical Center of Serbia, Belgrade, Serbia \\ ${ }^{2}$ Faculty of Medicine, University of Belgrade, Belgrade, Serbia \\ *Correspondence: Marija Nikolić, E-mail: nikolicmarija36@gmail.com \\ UDC 616.591/.594-002.4-091.8
}

\begin{abstract}
Acne necrotica is a rare disease, characterized by repeated cropping of inflammatory papules and papulo-pustules, which rapidly necrotize and leave varying degrees of varioliform scars that may lead to cicatricial alopecia when terminal hair-bearing sites are involved. In early lesions, pathology shows necrotizing lymphocytic folliculitis. We report a 63-year-old male patient with chronic, relapsing, umbilicated and centrally necrotic erythematous papules and papulo-pustules involving the frontal hairline area, face, and neck. Histopathology showed epidermal spongiosis and lymphocytic exocytosis, extensive necrosis and destruction of the follicular epithelium, a dense diffuse lymphohistiocytic infiltrate and necrosis of the perifolicular dermis. The diagnosis of acne necrotica was made based on the correlation of clinical and histopathological findings. A complete clinical remission was achieved with topical erythromycin and benzoyl peroxide.
\end{abstract}

Key words: Acne Vulgaris; Cicatrix; Necrosis; Alopecia; Folliculitis; Erythromycin; Benzoyl Peroxide; Treatment Outcome

\section{Introduction}

Acne necrotica is a puzzling disease, rarely described in the literature. Bazin first proposed the term acne necrotica in 1851 (1). Hebra named this condition as acne necrotica varioliformis based on the round depressed scars resulting from active disease. Sabouraud and Lane (in 1928 and a few years later, respectively) described a non-scarring superficial folliculitis, characterized by intensely pruritic, pinpoint pustules on the scalp, and called it acne necrotica miliaris (1). This form of acne necrotica surely should be differentiated from scarring varioliform variant, but it is still uncertain whether this condition represents a minor variant of the same disease
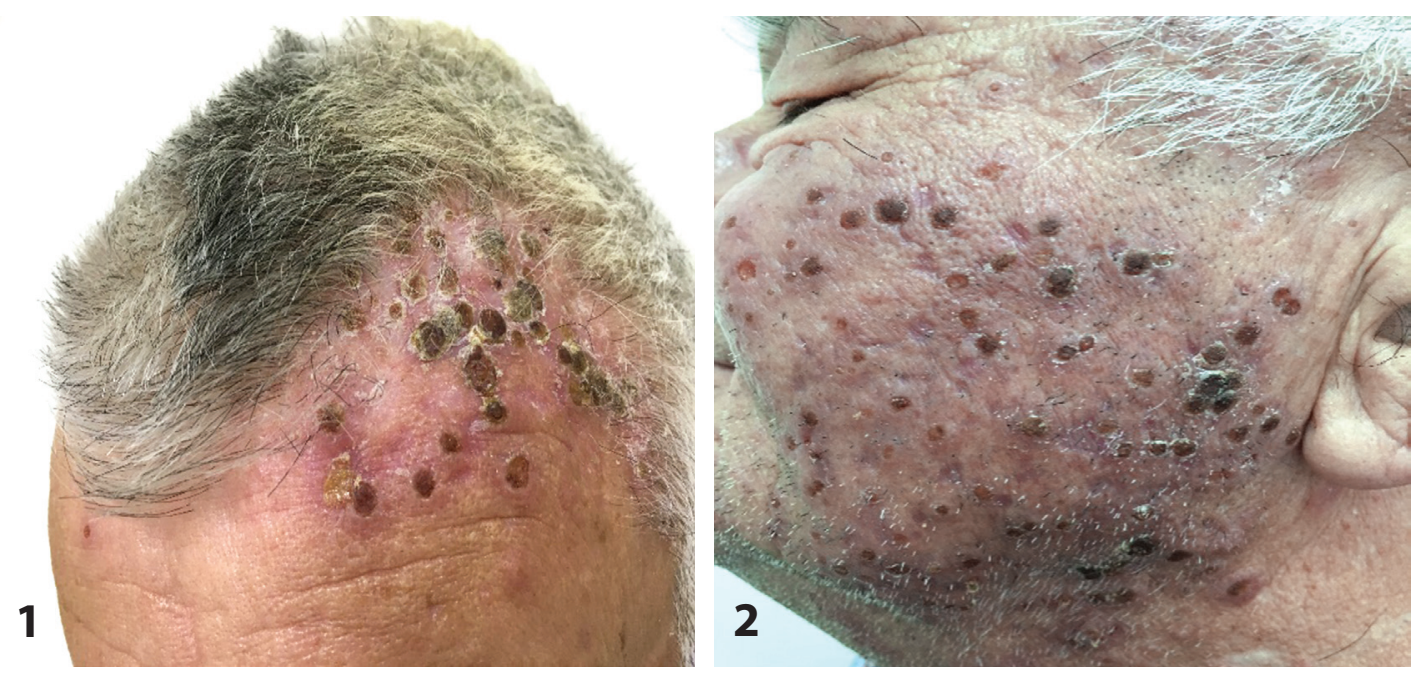

Figures 1 and 2. Multiple, grouped reddish-brown papules and papulo-pustules, partly umbilicated and centrally necrotic covered with round adherent hemorrhagic crusts 


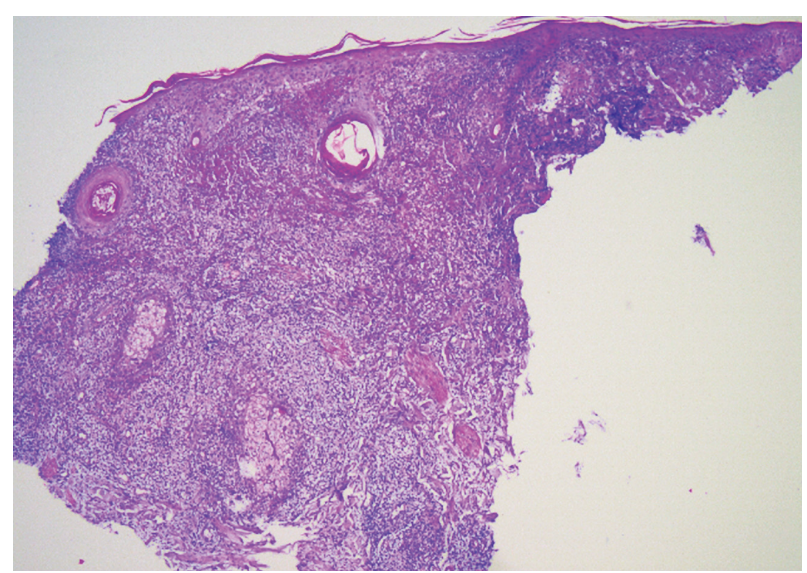

Figure 3. Histopathology showed epidermal spongiosis and lymphocytic exocytosis, extensive necrosis and destruction of the follicular epithelium, a dense diffuse lymphohistiocytic infiltrate and necrosis of the perifolicular dermis. (HE x40)

process or different entity (2). Other synonyms for acne necrotica are acne frontalis, acne atrophica, necrotizing lymphocyte folliculitis or pustular perifolliculitis $(2,3)$. Based on limited data, the disease affects more females than males and usually starts in the fourth and fifth decade of life $(3,4)$. The lesions generally present as grouped, erythematous papules and papulo-pustules, 2-5 $\mathrm{mm}$ in diameter that are umbilicated and within few days develop central necrosis, followed by an adherent hemorrhagic crust, which sheds after 3 or 4 weeks and result in varioliform scars $(2,5)$. In some patients, the appearance of the skin changes is accompanied by a burning sensation or pruritus (5). The most frequently affected areas are the frontal scalp and upper forehead, but the disease may also affect the nape, the nose, the cheeks, rarely extra facial regions like the chest and back $(3,5)$.

\section{Case Report}

A 63-year-old male patient with a 6-month history of multiple, relapsing papules and pustules in scalp and face was admitted to our Clinic. The patient complained about itching and burning sensations that followed the appearance of new lesions. His medical history was positive only for arterial hypertension, well-controlled with ramipril. He denied usage of any new medications. A year before presentation the patient had Herpes zoster infection affecting ophthalmic branch of the left trigeminal nerve. Physical examination revealed multiple, grouped reddish-brown
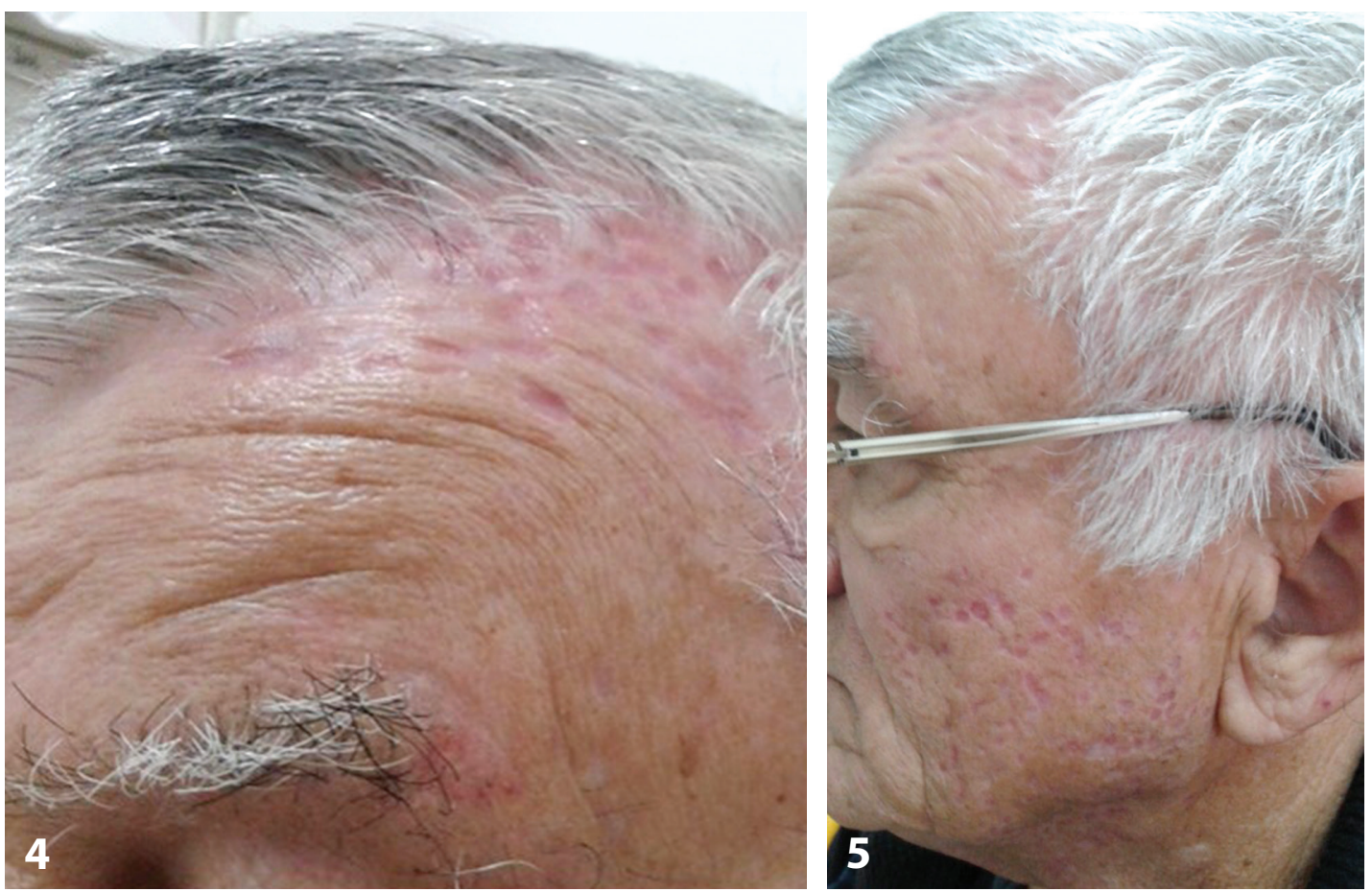

Figures 4 and 5. Residual varioliform scars and scarring alopecia 
papules and papulo-pustules, mostly umbilicated or centrally necrotic covered with round adherent hemorrhagic crusts, and depressed varioliform scars, distributed in frontal hairline, face, and neck (Figures 1 and 2). Skin biopsy was performed and histopathology showed epidermal spongiosis and lymphocytic exocytosis, extensive necrosis and destruction of the follicular epithelium, a dense diffuse lymphohistiocytic infiltrate and necrosis of the perifolicular dermis (Figure 3). Complete and differential blood cell count, sedimentation rate, routine biochemistry, Creactive protein, and protein serum electrophoresis were within the normal ranges. Hepatitis B, C, and HIV antibodies were negative. Bacterial swabs showed physiological flora and Demodex folliculorum was not found. Based on clinical and histopathological findings the diagnosis of acne necrotica was made. Treatment was started with topical erythromycin $2 \%$ cream and benzoyl peroxide $4 \%$ wash suspension. After two weeks of treatment, all lesions regressed with residual varioliform scars and scarring alopecia (Figures 4 and 5). There was no evidence of new lesions during the 6-month follow-up.

\section{Discussion}

Acne necrotica is a rare but clinically distinctive form of cicatricial alopecia with obscure pathogenesis. Most patients have an abnormal inflammatory reaction to the pathogenic microorganisms such as Propinibacterium acnes, Malassesia spp., Demodex folliculorum and, in more severe cases, Staphylococus aureus (7). Mechanical manipulations of pre-existing lesions such as rubbing and scratching may only exacerbate the disease but are not a cause $(3,6)$. Association of acne necrotica with phenylbutazone treatment has been reported in only one patient $(1,7)$. In rare cases of acne necrotica herpes simplex virus was identified in the lesions (6). The differential diagnosis is extensive and includes bacterial folliculitis, tinea capitis, eczema herpeticum, folliculitis decalvans, eosinophilic pustular folliculitis, pyoderma gangrenosum, cicatricial pemphigoid, blastomycosis-like pyoderma, erosive candidiasis of the scalp and pustular erosive dermatosis of the scalp, among other possibilities (1-3, 5, 6). Systemic and topical antibiotics, oral isotretinoin, systemic and intralesional corticosteroids, topical benzoyl peroxide and topical $0.005 \%$ calcipotriol cream have been recommended for the treatment of acne necrotica $(1-3,6,8)$. Doxepin has been suggested in patients manipulating skin lesions $(5,8)$. The clinical course is variable, with some cases showing spontaneous resolution and others resistant to therapy, where treatment can last for months with frequent recurrence of lesions (1).

\section{Conclusion}

Acne necrotica (varioliformis) represents a distinctive form of lymphocytic folliculitis with specific cutaneous involvement. Initially, only superficial parts of the follicles are involved $(2,9)$, therefore early and adequate intervention can enable recovery of the follicles and help new hair regrowth.

\section{References}

1. Ross EK, Shapiro J. Acne necrotica. In: Whiting D, Blume-Peytavi U, Tosti A, Trüeb RM, editors. Hair growth and disorders. Berlin, Heidelberg: SpringerVerlag; 2008. p. 216-8.

2. Ross EK, Tan E, Shapiro J. Update on primary cicatricial alopecias. J Am Acad Dermatol. 2005;53(1):1-37.

3. Plewig G, Melnik B, Chen WC. Acne necrotica (necrotizing lymphocytic folliculitis). In: Plewig G, Melnik B, Chen WC. Plewig and Kligman's acne and rosacea. 4th ed. Cham: Springer International Publishing; 2019. p. 318-9.

4. Restrepo R, Calonje E. Acne necrotica. In: Calonje E, Brenn T, Lazar A, McKee PH, editors. McKee's pathology of the skin with clinical correlations. Volume 2. 4th ed. Edinburg: Elsevier, Saunders; 2012. p. 1030.

5. Hay RJ, Adriaans BM. Acne necrotica. In: Burns T, Breathnch S, Cox N, Griffiths C, editors. Rook's textbook of dermatology. Volume 2. 8th ed. New York: NY John Wiley \& Sons; 2013. p. 30.26-7.

6. Plewig G, Kligman AM. Acne necrotica (necrotizing lymphocytic folliculitis). In: Plewig G, Kligman AM, editors. Acne and rosacea. 3rd ed. Berlin, Heidelberg: Springer-Verlag; 2000. p. 500-1.

7. Hunter GA. Acne necrotica due to phenylbutazone. Br Med J. 1959;1(5114):113.

8. Trüeb RM. The difficult hair loss patient. Zurich: Springer International Publishing; 2015. p. 141-2.

9. Kossard S, Collins A, McCrossin I. Necrotizing lymphocytic folliculitis: the early lesion of acne necrotica (varioliformis). J Am Acad Dermatol 1987;16(5 Pt 1):1007-14. 


\section{Acne necrotica (varioliformis): prikaz slučaja}

\section{Sažetak}

Acne necrotica su retka, misteriozna bolest, za koju su karakteristični rekurentni naleti pustula i papulopustula koje podležu centralnoj nekrozi i ostavljaju varioliformne ožiljke i cikatricijalnu alopeciju različitog stepena. U ranim lezijama histopapatološki nalaz karakteriše prisustvo nekrotizujućeg limfocitnog folikulitisa. Prikazujemo pacijenta starosti 63 godine, sa ponavljnim naletima papula i papulopustula na kapilicijumu, licu i vratu.
Histopatološki nalaz je odlikovalo prisustvo epidermalne spongioze i egzocitoza limfocita, ekstenzivna nekroza i destrukcija folikularnog epitela i gust, difuzan limfohistiocitni infiltrat i nekroza perifolikularnog derma. Dijagnoza je postavljena na osnovu kliničke slike i histopatološkog nalaza. Kompletna klinička remisija postignuta je lokalnom primenom eritromicina i benzoilperoksida.

Ključne reči: Acne vulgaris; Ožiljak; Alopecija; Folikulitis; Eritromicin; Benzoil peroksid; Ishod Terapije

Received 12.10.2019.

Accepted 25.10.2019. 